\title{
Ubiquitin and apoptosis in the corpus luteum of the marmoset monkey (Callithrix jacchus)
}

\author{
F. M. Young ${ }^{1 *}$, P. J. Illingworth ${ }^{2}$ and H. M. Fraser ${ }^{1}$ \\ ${ }^{i} M R C$ Reproductive Biology Unit, Centre for Reproductive Biology, 37 Chalmers Street, Edinburgh EH3 9EW, UK; \\ and ${ }^{2}$ Department of Obstetrics and Gynaecology, University of Sydney, NSW, Australia
}

\begin{abstract}
The polypeptide ubiquitin covalently binds to cytoplasmic proteins and marks them for proteolytic degradation. Ubiquitin is upregulated during apoptosis in some systems. Apoptosis increases during luteolysis but it is not known whether ubiquitin is expressed in regressing corpora lutea. Marmoset ovaries were removed on day 10 of the luteal phase from animals that had received either no treatment, treatment with the $\mathrm{PGF}_{2 \alpha}$ analogue cloprostenol $24 \mathrm{~h}$ earlier, or treatment with the GnRH antagonist antarelix for either 24 or $48 \mathrm{~h}$ before ovary collection. Ubiquitin was localized on ovarian sections by immunocytochemistry, and oligonucleosome formation characteristic of apoptosis was examined in isolated corpora lutea by electrophoresis of extracted [ $\left.{ }^{32} \mathrm{P}\right] \mathrm{DNA}$. Oligonucleosome formation was low in midluteal corpora lutea on day 10 but increased after induced luteal regression with $\mathrm{PGF}_{2 \alpha}$ and $\mathrm{GnRH}$ antagonist. Nuclear ubiquitin immunoreactivity was found in $1.66 \pm 0.66$ steroidogenic cells and cytoplasmic staining was found in $0.4 \pm 0.3$ steroidogenic cells (per $\times 40$ field of view) in midluteal phase corpora lutea on day 10 . Luteolytic induction with $\mathrm{PGF}_{2 \alpha}$ significantly increased the number of cells exhibiting cytoplasmic immunoreactivity to $12.24 \pm 1.6$ $(P<0.05)$. Ubiquitin immunoreactivity was not observed after $\mathrm{GnRH}$-induced luteal regression. Apoptotic oligonucleosome formation was found after induced luteal regression with both $\mathrm{PGF}_{2 \alpha}$ and $\mathrm{GnRH}$ antagonist, but ubiquitin upregulation only occurred after $\mathrm{PGF}_{2 \alpha}$-induced regression. These results indicate that ubiquitin expression is not specific for luteolysis and is not an indicator of luteal apoptosis, but that the polypeptide does play a role in luteal cellular responses to $\mathrm{PGF}_{2 \alpha}$.
\end{abstract}

\section{Introduction}

The corpus luteum of the ovary develops from a follicle after ovulation of an oocyte. Corpora lutea primarily produce the steroid hormone progesterone that is essential for the establishment and maintenance of pregnancy. If the ovulated oocyte is not fertilized and pregnancy does not occur, the corpus luteum ceases hormone production in a process known as functional luteal regression. It then undergoes structural luteal regression, characterized by cell death and the loss of luteal tissue.

In a non-fertile cycle the corpus luteum undergoes regression after a fixed species-specific period of time. This suggests that luteal cell death is programmed, and a number of studies have shown that luteal regression is associated with an increase in apoptosis (Orlicky et al., 1992; Juengel $e t$ al., 1993; Dharmarajan et al., 1994; Kenny et al., 1994; Zheng et al., 1994; Rueda et al., 1995; Young et al., 1997).

Ubiquitin is a highly conserved 76 amino acid polypeptide that covalently conjugates to cytoplasmic proteins and marks

*Present address: Department of Obstetrics and Gynaecology, The Queen Elizabeth Hospital, Woodville, SA 5011, Australia.

Received 15 December 1997. them for subsequent proteolytic degradation. Ubiquitin also binds to histones and may regulate chromatin structure during transcription (Hershko, 1988) and thus has been immunochemically detected in both the cytoplasm and the nucleus (Haas and Bright, 1985). Ubiquitin upregulation has been associated with apoptosis: in the tobacco hawkmoth, Manduca sexta, the developmentally programmed cell death of intersegmental muscles is associated with a tenfold increase in ubiquitin (Haas et al., 1996; Myer and Schwartz, 1996); the colonial sea squirt, Botryullus schlosseri, undergoes a cyclical cell death process characterized by apoptosis and upregulation of cytoplasmic ubiquitin immunoreactivity (Lauzon et al., 1993); and murine myoblasts committed to apoptosis show increased expression of ubiquitin (Sandri et al., 1997). Ubiquitin mRNA is upregulated and nuclear proteins are ubiquinated in human lymphocytes induced to undergo apoptosis (Delic et al., 1993). However, embryonic neurones induced to undergo apoptosis in vitro do not upregulate ubiquitin mRNA (D'Mello and Galli, 1993), which indicates that the role and subcellular localization of ubiquitin during apoptosis is not entirely clear.

Functional luteal regression in marmoset monkeys occurs 18-24 days after ovulation (Harding et al., 1982), but the 
entire process of regression can take approximately 2 weeks from the beginning of functional regression to the completion of structural regression. It is possible to shorten the duration of functional and structural luteolysis in marmosets by inducing luteal regression with either PGF (Summers of al., 1985; Fraser et al., 1995) or GnRH antagonist 9 days after ovulation (Hodges et al., 1988). Functional regression is complete and structural regression is well advanced $24 \mathrm{~h}$ after treatment (on day 10 of the luteal phase).

The aims of this study were: (i) to examine the expression of ubiquitin in the corpora lutea of marmoset monkeys after induced luteolysis; (ii) to confirm previous reports of an increase in apoptosis during structural luteal regression; and (iii) to assess ubiquitin as an early indicator of apoptotic cell death.

\section{Materials and Methods}

\section{Animals and troatments}

Female marmoset monkeys (Callithrix jacchus jacchus) were housed at the MRC Reproductive Biology Unit Primate Centre as described by Hearn et al. (1975). All procedures were carried out in accordance with the Animals (Scientific Procedures) Act 1986. Ovarian cycles were monitored by taking venous blood samples on alternate days and measuring the plasma progesterone concentration (Smith et al., 1990). The follicular phase was defined as the period during which progesterone concentrations were $20 \mathrm{nmol} \mathrm{l}^{-1}$ or less. Day 1 of the luteal phase was assumed to be the day on which the progesterone concentration rose above $32 \mathrm{nmol} \mathrm{l}^{-1}$ and was followed by a sustained elevation in progesterone.

Animals were monitored before inclusion in the study to ensure ovarian cycles were normal. Ovaries were collected as described by Young et al. (1997). Briefly, animals were treated on day 9 of the luteal phase with either the GnRH antagonist antarelix (1 mg kg-1 s.c.; Europeptides, Argenteuil) (Deghenghi et al., 1993) or the $\mathrm{PGF}_{2 \mathrm{x}}$ analogue cloprostenol (1 $\mu$ g i.m.; Planate, Coopers Animal Health Ltd, Crewe) (Summers ot al., 1985; Fraser et al., 1995). Ovaries were collected $24 \mathrm{~h}$ after luteolytic treatment $(n=6$ for both treatments) and were compared with ovaries obtained from untreated animals on day 10 of the luteal phase $(n=7)$. One additional animal was treated with GnRH antagonist on days 8 and 9 of the luteal phase and ovaries were collected on day 10 .

\section{Tissue collection and preparation}

Animals were sedated with $100 \mu$ l ketamine hydrochloride (200 $\mathrm{mg} \mathrm{ml}^{-1}$; Parke-Davies Veterinary, Pontypool) administered i.m. and then killed with $400 \mu \mathrm{l}$ Euthatal administered i.v. (100 mg sodium pentobarbitone $\mathrm{ml}^{-1}$; Rhône Mérieux, Harlow). A terminal blood sample was taken before removing ovaries. Ovaries for immunocytochemical analysis were fixed in $4 \%(\mathrm{w} / \mathrm{v})$ buffered paraformaldehyde for $24 \mathrm{~h}$ before embedding in paraffin wax according to standard procedures. Sections $(4 \mu \mathrm{m})$ were mounted on slides coated with poly-L-lysine $\left(50 \mu \mathrm{g} \mathrm{I}^{-1}\right)$. Corpora lutea were dissected free of ovaries (day 10 of luteal phase controls, $n=4 ; 24 \mathrm{~h}$ after $\mathrm{PGF}_{2 \alpha}$ treatment, $n=3 ; 24 \mathrm{~h}$ after GnRH antagonist treatment, $n=3$; and $48 \mathrm{~h}$ after $\mathrm{GnRH}$ antagonist treatment, $n=1)$ and snap-frozen in liquid nitrogen for DNA extraction and analysis of oligonucleosome formation. Liver samples were also collected and frozen for use as negative control tissues in the oligonucleosome study.

\section{Immunocytochemistry}

Paraformaldehyde fixed sections were rehydrated through graded alcohols to water then subjected to antigen retrieval by exposure to four $5 \mathrm{~min}$ cycles of microwave irradiation at $700 \mathrm{~W}$ in $0.01 \mathrm{~mol}$ sodium citrate $1^{-1}$ buffer $(\mathrm{pH} 6.0)$ as described by Shi et al. (1993). The sections were then cooled at room temperature for $20 \mathrm{~min}$ before washing in Tris-buffered

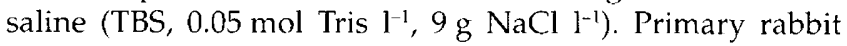
anti-bovine ubiquitin polyclonal antibody (DAKO, High Wycombe) was diluted 1:50 in TBS and applied for $36 \mathrm{~h}$ at $4^{\circ} \mathrm{C}$. Corresponding negative controls were treated with 1:50 normal rabbit serum (SAPU, Carluke). After washing with TBS, secondary antibodies were applied in a blocking solution as follows: biotinylated goat anti-rabbit 1:500 (DAKO, High Wycombe) in 20\% normal goat serum, $5 \%$ BSA $(w / v)$ in TBS for $1 \mathrm{~h}$ at room temperature. Visualization was with avidin-biotin complex conjugated to alkaline phosphatase (Vector, Peterborough) made up according to the manufacturer's instructions and applied for $1 \mathrm{~h}$ at room temperature, followed by application of Fast Red stain made up to the manufacturer's instructions (Vector, Peterborough).

\section{Ubiquitin quantification and statistics}

Slide identification was obscured and independent assessment of qualitative differences between treatments was carried out by two observers. Quantitative analysis was also conducted blind using a $\times 40$ objective lens. Six randomly selected fields of view of luteal tissue were scored for each animal and the mean number of ubiquitin-positive cells per $\times 40$ field of view was calculated for each animal. Scoring more than five fields of view did not significantly alter the accumulative mean. Localization of ubiquitin to either the nucleus or the cytoplasm was also recorded. Mean numbers were calculated for each experimental group and expressed as mean \pm SEM. A two-tailed paired Student's $t$ test was applied to day 10 controls and to each of the two treatment groups. Significance was assigned at $P<0.05$.

\section{DNA extraction and oligonucleosome detection}

Cellular DNA was extracted and the 3' ends were labelled using a method modified from Tilly and Hsueh (1993). Luteal tissue (approximately $20 \mathrm{mg}$ ) was homogenized in

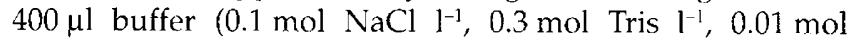
EDTA $1^{-1}$ and $0.2 \mathrm{~mol}$ sucrose $\mathrm{1}^{-1}, \mathrm{pH} 8$ ) with a handheld 
electric homogenizer (Polytron PT 1200B92; Phillip Harris Co. Ltd, Glasgow) and then incubated at $65^{\circ} \mathrm{C}$ for $2-3 \mathrm{~h}$ with the addition of $25 \mu \mathrm{l}$ of $10 \%(\mathrm{w} / \mathrm{v})$ SDS and $25 \mu \mathrm{l}$ of $0.01 \mathrm{mg}$ proteinase- $\mathrm{K}_{\mu \mathrm{l}^{-1}}$ (Boehringer Mannheim, Lewes). After incubation, samples were centrifuged at $5000 \mathrm{~g}$ for $20 \mathrm{~min}$ at $4^{\circ} \mathrm{C}$. The supernatant was collected and nucleic acids were extracted first with phenol:chloroform:isoamyl alcohol (25:24:1) and subsequently with chloroform:isoamyl alcohol (24:1). DNA $(15 \mu \mathrm{l})$ and the following reagents were used for 3' labelling: $15 \mu \mathrm{l}$ of $5 \times$ reaction buffer ( $1 \mathrm{~mol}$ potassium cacodylate $\mathrm{l}^{-1}, 0.125 \mathrm{~mol}$ Tris-Cl $\mathrm{l}^{-1}, 1.25 \mathrm{mg} \mathrm{BSA} \mathrm{m}^{-1}, \mathrm{pH}$

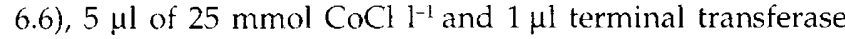

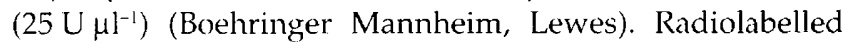
dideoxynucleotide $\left(2 \mu\right.$ of $\left[\alpha^{-32} \mathrm{P} \mid \mathrm{ddATP}\left(110 \mathrm{TBq}^{\mathrm{mmol}}{ }^{-1}\right)\right.$, Amersham International, Amersham) was added before incubation at $37^{\circ} \mathrm{C}$ for $60 \mathrm{~min}$. The reaction was terminated

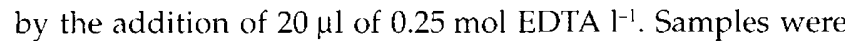
loaded onto Sephadex G50 Nick Spin Columns (Pharmacia, Uppsala) and centrifuged at $500 \mathrm{~g}$ for $5 \mathrm{~min}$ to separate DNA-bound radionucleide from free radionucleide. Labelled DNA was subjected to electrophoresis on a $2 \%$ agarose gel for $2.5 \mathrm{~h}$ at $85 \mathrm{~V}$ using a $1 \times$ TAE $(40 \mathrm{mmol}$ Tris-acetate $\mathrm{l}^{-1}, 1 \mathrm{mmol}$ EDTA $\mathrm{l}^{-1}$ ) running buffer. The gel was dried and exposed to Kodak X-Omat AR film for 2-12 h at $-72^{\circ} \mathrm{C}$. DNA extraction and labelling was conducted at least twice on each sample.

\section{Progesterone assay}

Progesterone concentrations were determined by radioimmunoassay as described by Smith et al. (1990). The sensitivity of the assay was 0.07 pmol per tube and the interand intra-assay coefficients of variation were 15 and $4 \%$, respectively. The means of each group were expressed \pm SLM and subjected to a two-tailed Student's $t$ test with significance assigned at $P<0.01$.

\section{Results}

On the day of ovary collection progesterone concentrations were at luteal phase values $311 \pm 48 \mathrm{nmol} \mathrm{l}^{-1}(n=3)$ in all midluteal phase control animals but were significantly reduced to $18.33 \pm 3.75 \mathrm{nmol} \mathrm{l}^{-1}(P<0.01, n=3)$ and $36.35 \pm$ $16.32 \mathrm{nmol} \mathrm{l}^{-1}(P<0.01, n=3)$ after luteolytic treatment with $\mathrm{PGF}_{2 x}$ and induction of luteolysis with GnRH antagonist, respectively.

Low oligonucleosome formation was observed in one midluteal phase animal on day 10 (Fig. 1, lane 1), but apoptotic DNA fragmentation was absent from three other midluteal phase animals (results for two animals are shown in Fig. 1, lanes 2 and 3). Oligonucleosome fragmentation was present in all animals after induced regression with either GnRH antagonist (Fig. 1, lanes 4 and 5) or PGF 2 (Fig. 1, lanes 6 and 7). Smearing was also observed, which is indicative of non-apoptotic DNA degradation. This was inconsistent in control samples, but non-apoptotic DNA fragmentation was always present in the corpora lutea of animals given luteolytic treatments. DNA fragmentation was not observed in the liver samples.
Luteolytic treatment with either $\mathrm{PGF}_{2,}$ or GnRH antagonist caused changes in the morphological appearance of corpora lutea from regular organized tissue consisting of large rounded steroidogenic cells (Webley it al., 1990; Fehrenbach et al., 1995) embedded in a vascular network of capillaries and small blood vessels, to a disorganized irregular structure in which the vasculature was dilated and the parenchymal cells were oedematous with cytoplasmic vacuoles. Ubiquitin immunostaining was localized in the nuclei of steroidogenic cells $(1.66 \pm 0.66$ cells per $\times 40$ field of view, $n=3$, Figs 2 a and 3 ) in midluteal phase corpora lutea on day 10 , but was not found in the nuclei of luteal cells after luteolytic treatment (Fig. 3). Cytoplasmic ubiquitin immunoreactivity was apparent in $0.4 \pm 0.3$ midluteal phase cells per $\times 40$ field of view, and this was significantly increased to $12.24 \pm 1.6$ cells $(P<0.02, n=3)$ per $\times 40$ field of view in $P \mathrm{FF}_{2 c x}$-treated animals (Figs $2 \mathrm{C}$ and 3 ). Ubiquitin immunoreactivity was not observed after induction of luteolysis with GnRH antagonist (Fig. 2d), nor was it found in negative control sections (Fig. $2 \mathrm{~b}$ ).

\section{Discussion}

This is the first report of cytoplasmic ubiquitin upregulation after $\mathrm{PGF}_{2(x)}$-induced luteolysis in a primate. GnRH antagonist-induced luteolysis did not cause an increase in ubiquitin expression. Oligonucleosome formation characteristic of apoptotic DNA fragmentation increased after induced luteal regression with both $\mathrm{PGF}_{2 y}$ and $\mathrm{GnRH}$ antagonist, which suggests that ubiquitin expression is not related to apoptosis in marmoset luteal regression.

Ubiquitin was found in the nuclei of a small number of midluteal phase steroidogenic cells, and it has previously been shown that $<1 \%$ of steroidogenic cells become $3^{\prime}$ labelled in situ during the midluteal phase (Young ot al., 1997). Therefore, nuclear ubiquitin may be related to apoptosis during the midluteal phase. However, it is also possible that it has a role in transcription and cell cycle protein regulation (Levinger and Varhavsky, 1982; Huang et al. 1986). Ubiquitin was also found in the cytoplasm of parenchymal luteal cells $24 \mathrm{~h}$ after induction of luteolysis with $\mathrm{PGF}_{2 a}$. The shift from nucleus to cytoplasm and the increase in the number of cells expressing ubiquitin suggests that ubiquitin has different roles before and after luteolysis, and may be involved in cytoplasmic proteolysis or protein regulation during $\mathrm{PGF}_{2 x}$-induced luteal regression. Murdoch et al. (1996) reported an increase in luteal ubiquitin mRNA and protein as rapidly as $2 \mathrm{~h}$ after administration of a luteolytic dose of $\mathrm{PGF}_{2 x}$ to ewes. This observation suggests that ubiquitin is involved in functional luteal regression, since structural regression, as measured by total luteal mass, did not begin until at least $16 \mathrm{~h}$ after administration of $\mathrm{PGF}_{2,}$ in this study. However, this does not preclude ubiquitin from involvement in structural regression. Ubiquitin immunoreactivity was not found in any animal subjected to GnRH antagonist-induced luteolysis. These data suggest that ubiquitin was not involved in structural regression in GnRH antagonist-treated animals, although it is possible that ubiquitin expression occurred earlier and was involved 


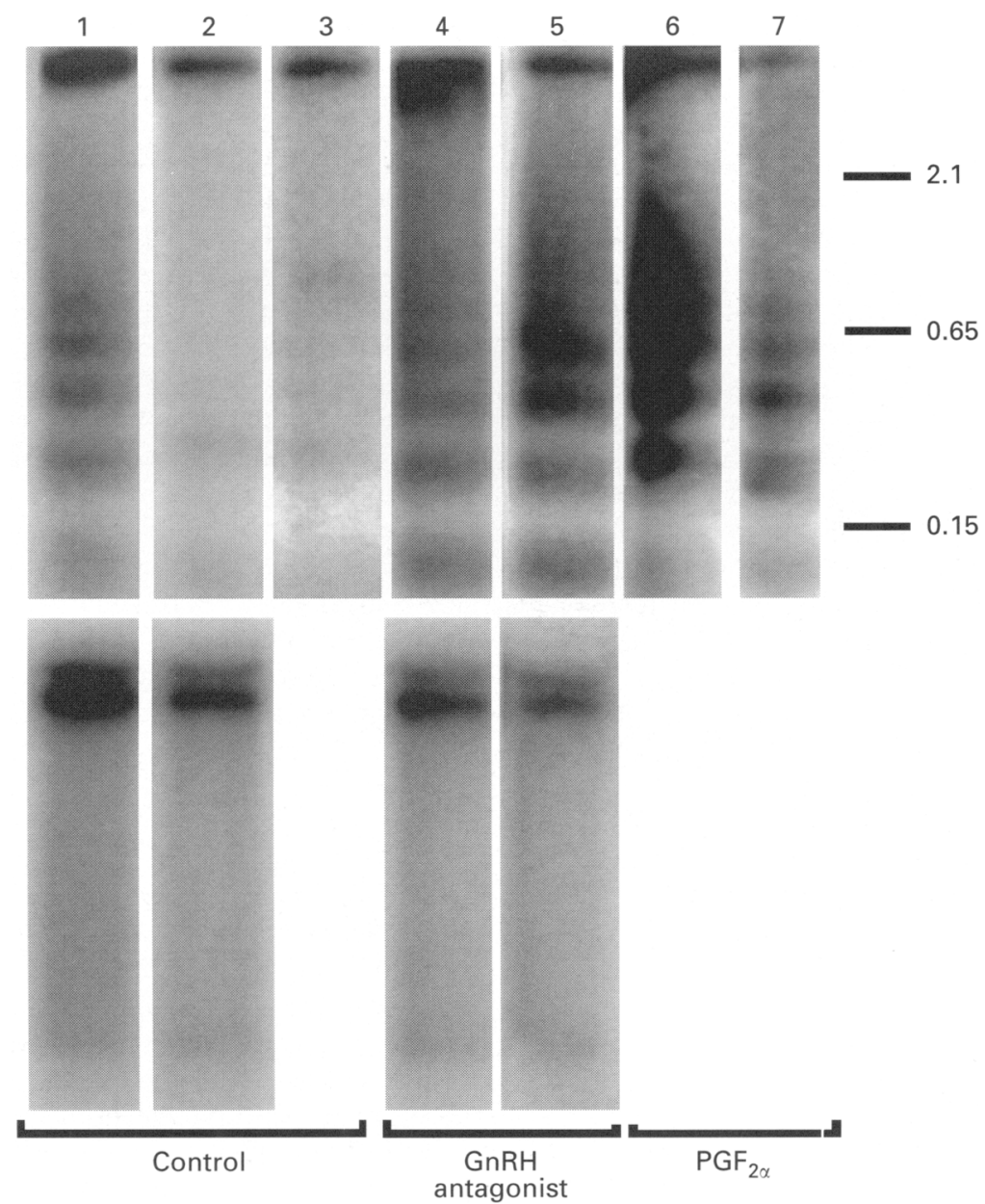

Fig. 1. Autoradiograph of 3'-labelled DNA from marmoset corpora lutea subjected to electrophoresis on a $2 \%$ agarose gel. Lanes $1-3$, midluteal phase controls; lanes 4 and 5, GnRH antagonist administered in vivo on day 9 of the luteal phase; lanes 6 and 7, PGF 2 administered in vivo on day 9 of the luteal phase. All corpora lutea were collected on day 10 of the luteal phase. Lower lanes show negative control liver samples corresponding to the animal in the lane above. Molecular weight markers are shown on the right hand side.

in functional luteal regression. Therefore, ubiquitin expression in luteal cells may be a response to prostaglandin because only cells with prostaglandin receptors expressed ubiquitin in ovine corpora lutea (Murdoch et al., 1996). Furthermore, luteal ubiquitin expression may not be specific for luteolysis but forms part of a response to cellular stress in which ubiquitin is coexpressed with heat shock protein 70 (Murdoch et al., 1996), which is upregulated after PGF $_{20 x^{-}}$ induced regression in rats (Khanna et al., 1995).

Apoptosis has been shown to occur during structural luteolysis (Murdoch, 1995). The extent of oligonucleosome formation observed in marmoset corpora lutea in the present study confirms previous observations that showed an increase in apoptosis after luteolytic treatment (Young et al., 1997). The small amount of oligonucleosome formation in midluteal corpora lutea observed in the present study is in agreement with the small amount of in situ 3' labelling previously observed in these animals, in which $<1 \%$ of cells undergo apoptosis during the midluteal phase (Young et al.,
1997). Luteolytic treatment with $\mathrm{PGF}_{2 \alpha}$ or $\mathrm{GnRH}$ antagonist increased apoptotic cell numbers to $8.04 \pm 1 \%$ and $7.4 \pm 1.5 \%$, respectively, in 3-labelled sections, and there was a corresponding increase in apoptotic oligonucleosome formation $24 \mathrm{~h}$ after induction of luteolysis with both $\mathrm{PGF}_{2 \alpha}$ and $\mathrm{GnRH}$ antagonist. Oligonucleosome formation $24 \mathrm{~h}$ after induction of luteolysis with $\mathrm{PGF}_{2 \alpha}$ has also been reported in bovine (Juengel et al., 1993; Rueda et al., 1995), ovine (Kennny et al., 1994), and rabbit (Dharmarajan et al., 1984) corpora lutea, but there has been no other demonstration of oligonuclosome formation after a luteolytic dose of $\mathrm{GnRH}$ antagonist. Non-specific DNA degradation has been associated with necrotic cell death, and parenchymal luteal cells in the present study displayed some characteristics of necrosis after luteolytic treatment (that is, DNA margination, formation of cytoplasmic vacuoles and oedematous swelling). The non-specific DNA fragmentation observed after induced luteal regression may be attributable to this particular form of cell death. 

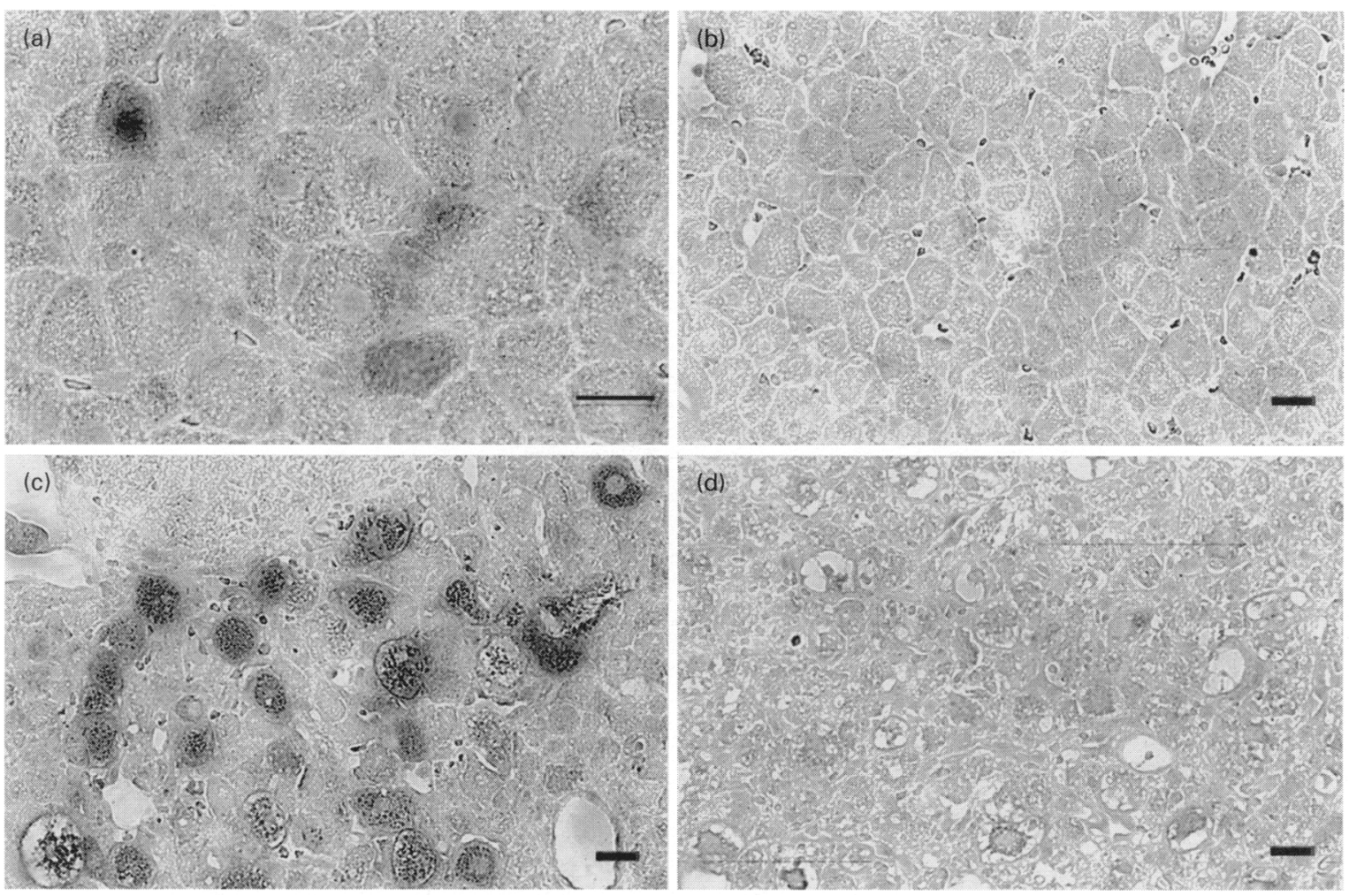

Fig. 2. Immunohistological detection of ubiquitin in $4 \mu \mathrm{m}$ sections of paraffin wax-embedded marmoset ovaries using the avidin-biotin alkaline-phosphatase method. Dark grey to black areas represent positive immunoreactivity. (a) Ubiquitinpositive nucleus and cytoplasm of steroidogenic cells in a corpus luteum on day 10 of the luteal phase. (b) Negative control section for (a) with primary ubiquitin antibody omitted; no positive immunoreactivity. (c) Ubiquitin-positive cytoplasm in steroidogenic cells in a regressed corpus luteum on day 10 of the luteal phase $24 \mathrm{~h}$ after administration of $\mathrm{PGF}_{2 \alpha}$ analogue. (d) No ubiquitin immunoreactivity in regressed corpora lutea on day 10 of the luteal phase $24 \mathrm{~h}$ after administration of $\mathrm{GnRH}$ antagonist. Scale bars represent $20 \mu \mathrm{m}$.

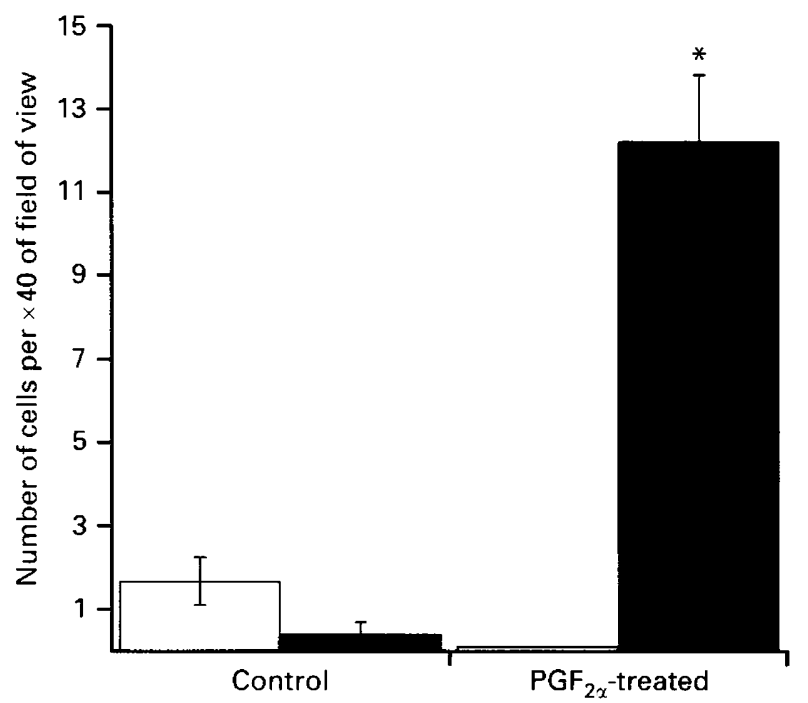

Fig. 3. Mean ( \pm SEM) number of luteal cells exhibiting either nuclear $(\square)$ or cytoplasmic $(\square)$ ubiquitin immunoreactivity per $\times 40$ field of view in paraformaldehyde-fixed sections of marmoset ovaries. Ovaries were collected on day 10 of the luteal phase from control animals $(n=3)$ and from animals treated $24 \mathrm{~h}$ previously with a $\mathrm{PGF}_{2 \alpha}$ analogue $(n=3)$. Asterisk indicates value is significantly different $(P<0.02)$ from corresponding midluteal phase control.
Ubiquitin has been shown to be upregulated during apoptosis in a number of systems (Delic et al., 1993; Lauzon et al., 1993; Haas et al., 1996; Myer and Schwartz, 1996; Sandri et al., 1997). However, there does not seem to be a relationship between ubiquitin expression and apoptosis during luteal regression in marmoset monkeys. Cells expressing ubiquitin in $\mathrm{PGF}_{2 \alpha}$-treated animals did not have the same morphology as 3-labelled cells in serial sections; death of ubiquitin-positive cells appeared to be by a nonapoptotic autophagocytotic pathway. In addition, apoptosis has been demonstrated $24 \mathrm{~h}$ after administration of $\mathrm{GnRH}$ antagonist (Young et al., 1997) but this is not coincident with ubiquitin expression in these animals.

In conclusion, ubiquitin is expressed in the nuclei of a small number of midluteal phase steroidogenic cells and in the cytoplasm of steroidogenic cells after $\mathrm{PGF}_{2 \alpha}$-induced luteal regression, but is not expressed in luteal cells after a luteolytic dose of GnRH antagonist. Induced luteolysis with both $\mathrm{PGF}_{2 \alpha}$ and $\mathrm{GnRH}$ antagonist is associated with an increase in apoptosis, but ubiquitin expression is not an indicator of apoptosis in the corpus luteum of marmoset monkeys.

The authors thank K. D. Morris and staff for animal care, Ian Swanston and staff for progesterone assay, M. Miller and Sheila 
MacPherson for skilled technical support, and R. Deghenghi (Europeptides) for the gift of antarelix.

\section{References}

Deghenghi R, Boutignon F, Wuthrich P and Lenaerts V (1993) Anterelix (EP 24332) a novel water soluble LHRH antagonist Biomedicine and Pharmacotheraply 47 107-110

Delic J, Morange M and Magdelenat H (1993) Ubiquitin pathway involvement in human lymphocyte gamma irradiation induced apoptosis Molecular Cell Biology 13 4875-4883

Dharmarajan AM, Goodman SB, Tilly KI and Tilly JL (1994) Apoptosis during functional corpus luteum regression: evidence of a role for chorionic gonadotropin in promoting luteal cell survival Endocrine lournal 2295-303

D'Mello SR and Galli C (1993) SGP2, ubiquitin, 14K lectin and RP8 mRNAs are not induced in neuronal apoptosis Neuroreport 4355-358

Fehrenbach A, Einspanier A, Nicksch E and Hodges JK (1995) Assessment of tissue integrity, ultrastructure and steroidogenic activity of corpora lutea of the marmoset monkey, Callithrix jacchus, following in vitro microdialysis Tissue and Cell $27467-481$

Fraser HM, Lunn SF, Cowen G and Illingworth PJ (1995) Induced luteal regression in the primate: evidence for apoptosis and changes in c-myc protein Journal of Endocrinology 147 131-1.37

Haas AL and Bright PM (1985) The immunochemical detection and quantification of intracellular ubiquitin-protein conjugates The Journat of Biological Chemistry $26012464-12473$

Haas AL, Baboshina O, Williams B and Schwartz LM (1996) Coordinated induction of the ubiquitin conjugation pathway accompanies the developmentally programmed death of insect skeletal muscle journal of Biological Chemistry 2709407-9412

Harding RD, Hulme MJ, Lunn SF, Henderson C and Aitken RJ (1982) Plasma progesterone levels throughout the ovarian cycle of the common marmoset (Callitirix iachins). Joumal of Medical Primatology 11 43-51

Hearn JP, Lunn SF, Burden FJ and Pilcher MM (1975) Management of marmosets for biomedical research Laboratory Animals 9 125-134

Hershko A (1988) Ubiquitin-mediated protein degradation The fournul of Biological Clemistry 26315237-15241

Hodges JK, Cottingham PG, Summers PM and Yingnan L (1988) Controlled ovulation in the marmoset monkey (Callithrix jacthus) with human chorionic gonadotrophin following prostaglandin-induced luteal regression Firtility and Stcrility 48 299-305

Huang SI, Barnard MB, Xu M, Matsui SI, Rose SE and Garrard WT (1986) The active immunoglobulin $\kappa$ chain gene is packaged by non-ubiquitinconjugated nucleosomes Procedings Nutionnl Acadeny of Sciences USA 83 3738-3742

Juengel JL, Garverick HA, Johnson AI, Youngquist RS and Smith MF (1993) Apoptosis during luteal regression in cattle Endocrinology 132 250-254

Kenny N, Williams RE and Kelm LB (1994) Spontaneous apoptosis of cells prepared from the non-regressing corpus luteum Biochemistry and $\mathrm{Cell}$ Biology $72531-536$
Khanna A, Aten R and Behrman $\mathbf{H}$ (1995) Heat shock protein-70 induction mediates luteal regression in the rat Molecular Endocrinology/ 9 1431-1440

Lauzon RJ, Patton CW and Weissman IL (1993) A morphological and immunohistochemical study of programmed cell death in Botryllus schlosseri (Tunicata, Ascidiacea) Cell Tissue Reserurch 272 115-127

Levinger $\mathbf{L}$ and Varhavsky A (1982) Selective arrangement of ubiquitinated and D1 protein-containing nucleosomes within the Drosophila genome $\mathrm{C}$ ell $28375-385$

Murdoch WJ (1995) Temporal relationships between stress protein induction progesterone withdrawal and apoptosis in corpora lutea of ewes treated with prostaglandin F2 alpha Journal of Animal Science 73 1789-1792

Murdoch WJ, Austin KA and Hansen TR (1996) Polyubiquitin upregulation in corpora lutea of prostaglandin treated ewes Endocrinology $1374526-4529$

Myer A and Schwartz LM (1996) Allelic variation of the polyubiquitin gene in the tobacco hawkmoth, Manduca sexfa, and its regulation by heat shock and programmed cell death Insect Biochemistry and Molecular Biology 26 $1037-1046$

Orlicky DJ, Fisher L, Dunscombe N and Miller GJ (1992) Immunohistochemical localisation of PGF2 $\alpha$ receptor in the rat ovary Prostaglandins Leukotrienes and Essential Fatty Acids 46 223-229

Rueda BR, Wegner JA, Marion SL, Wahlen DD and Hoyer PA (1995) Internucleosomal DNA fragmentation in ovine luteal tissue associated with in vizo and in vitro analysis Binlegy of Reproduction 52 305-312

Sandri M, Podhorska-Okolow M, Geromel V, Rizzi C, Arslan P, Franceschi $C$ and Carraro $U$ (1997) Exercise induces myonuclear ubiquitination and apoptosis in dystrophin-deficient muscle of mice Journal of Neuropathology and Experimental Neurology 56 45-57

Shi S, Chaiwun B and Young $\mathbf{L}$ (1993) Antigen retrieval technique utilizing citrate buffer or urea solution for immunohistochemical demonstration of androgen receptor in formalin-fixed paraffin sections fournal of Histochemical Cytochemistry 41 1599-1604

Smith KB, Lunn SF and Fraser HM (1990) Inhibin secretion during the ovulatory cycle and pregnancy in the common marmoset monkey fournal of Entocrinology $126489-495$

Summers PM, Wennink CJ and Hodges JK (1985) Cloprostenol induced luteolysis in the marmoset monkey (Callithrix jacthus). fournal of Reproduction and Fertility 73 133-1,38

Tilly JL and Hsueh AJW (1993) Microscale autoradiographic method for the qualitative and quantitative analysis of apoptosis fournal of Cellular Physiology $154519-526$

Webley GE, Richardson MC, Smith CA, Masson GM and Hearn JP (1990) Size distribution of luteal cells from pregnant and non-pregnant marmoset monkeys and a comparison of the morphology of marmoset luteal cells with those from the human corpus luteum lournal of Reproduction and F'rtility $90427-437$

Young FM, Illingworth PJ, Lunn SF, Harrison DJ and Fraser HM (1997) Cell death during luteal regression in the marmoset monkey foumnal of Reproduction and Fertility $111109-119$

Zheng J, Fricke PM, Reynolds LP and Redmer DA (1994) Evaluation of the growth, cell proliferation and cell death in bovine corpora lutea throughout the estrous cycle Biology of Reproduction 51 623-632 